\title{
NEW DATA ON CHRONOLOGY OF LANDSCAPE-PALEOCLIMATIC STAGES IN NORTHWESTERN RUSSIA DURING THE LATE GLACIAL AND HOLOCENE
}

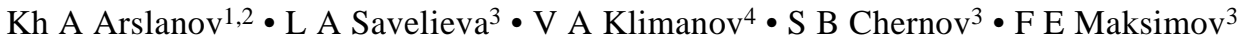 \\ T V Tertychnaya ${ }^{3} \cdot$ D A Subetto $^{4}$
}

\begin{abstract}
Two lake and bog sediments have been thoroughly studied using palynological and radiocarbon dating methods. These are the Lembolovskoye Lake section located in the southern part of the Karelian Ithmus and the Mshinskoye bog section located in the southwestern part of the Leningrad province. The data obtained allow us to reconstruct the main features of the vegetation cover evolution, the chronology for the appearance and a real distribution of the main arboreal species from the south of the Leningrad province to the north, and to construct curves of the paleoclimate parameter changes for the area under study. Thirty-six ${ }^{14} \mathrm{C}$ dates were obtained for the Lembolovskoye Lake section (7 m thick). According to those dates, the organic gyttja formation in the lake began $9870 \pm 170$ BP. Spore-pollen spectra with high percentage of herbs, arborescent, and shrub-birch dated back to the Younger Dryas were found out in clay layers at a depth of $6.5 \mathrm{~m}$. An appearance of spruce and alder pollen is dated at $6860 \pm 120$ and $7510 \pm 150 \mathrm{BP}$, respectively. The maximal percentage of broad-leaved species falls on the first half of the Atlantic (AT-1). Thirty-two dates were obtained for the Mshinskoye bog section (6 m thick): from 60 \pm 70 to $9520 \pm 170 \mathrm{BP}$ (the last date fixed the beginning of peat formation); 12 palinozones from the Preboreal to the Subatlantic were recognized there. The spruce and alder pollen began to appear $7520 \pm 110$ and $7670 \pm 130 \mathrm{BP}$, respectively. The maximal amount of broad-leaved species is observed at $4690 \pm 80 \mathrm{BP}$. The detailed reconstruction of changes in vegetation communities during the Late Glacial and Holocene was correlated with paleoclimatic characteristics, which have been reconstructed for the sections under study by using the information from a statistical method of spore-pollen data processing.
\end{abstract}

\section{INTRODUCTION}

During 1993-1999 we carried out systematically paleobotanical and geochronological investigations of continuously formed bog and lake sediments in northwestern Russia. The study was undertaken to reconstruct the stages of changing vegetation and paleoclimates during the Late Glacial and Holocene. The results of the study for five reference sections in the Leningrad and Novgorod provinces and two sections in Karelia, for which 320 radiocarbon dates have been obtained, were published earlier (Arslanov et al. 1999; Elina et al. 1996). Later, in 1998-1999, using the unified procedure we studied two more sections in the Leningrad province: the Lembolovskoye Lake and the Mshinskoye bog. The object was to obtain additional paleobotanical and geochronological data for more precise definition and detailing of the stages mentioned above.

\section{METHODS}

We analyzed palynologically every $10-\mathrm{cm}$ layer of continuously formed bog and lake sediments along the whole section and the great majority of the layers were radiocarbon dated at the Geochronological Laboratory of the Geographical Research Institute, St. Petersburg University. The pretreatment of samples (peat and gyttja), the benzene synthesis from the pretreated samples and the ${ }^{14} \mathrm{C}$ activity measurements in the synthesized samples were carried out by the procedures published earlier (Arslanov et al. 1993). For palynological analysis the peat and gyttja samples were boiled in $10 \% \mathrm{NaOH}$ for $5 \mathrm{~min}$, then rinsed by distilled water and the residue was separated by centrifugation and then analyzed. The pretreatment of mineralized samples or samples with a small amount of organic matter was carried out by the procedure described in Arslanov et al. (1999), which allows us to separate organic and mineral fractions by using a heavy liquid (PD-6 or KK-2.6). The percentage

\footnotetext{
${ }^{1}$ Geographical Research Institute, St. Petersburg State University, Sredny pr., 41, St. Petersburg 199004, Russia

${ }^{2}$ Corresponding author. Email: ArslanovKh@mail.ru.

${ }^{3}$ Institute of Geography, Russian Academy of Sciences, Staromonetny Lane, 29, Moscow 109017, Russia

${ }^{4}$ Institute of Limnology, Russian Academy of Sciences, Sevostianov’s Str., 9, St. Petersburg 196105, Russia
}

(C) 2001 by the Arizona Board of Regents on behalf of the University of Arizona

Radiocarbon, Vol 43, Nr 2B, 2001, p 581-594

Proceedings of the 17th International ${ }^{14} \mathrm{C}$ Conference, edited by I Carmi and $\mathrm{E}$ Boaretto 
of arboreal pollen and shrub groups (AP) and herbs (NAP), individual arboreal and herb species and also spores was calculated taking the total pollen AP and NAP sum as $100 \%$. Using the TILIAGRAPH computer program the chrono-palynological diagrams were constructed.

\section{RESULTS}

\section{Lembolovskoye Lake Section $\left(60^{\circ} 21^{\prime} 45^{\prime \prime} \mathrm{N}, 30^{\circ} 18^{\prime} 80^{\prime \prime} \mathrm{E}\right)$}

Lembolovskoye Lake is located on the eastern slope of the Karelian Highland. It is shallow (average depth 1.5-2.0 m), stretched out from the north to the south (9 km long, $2 \mathrm{~km}$ wide at the maximum), divided into two parts by a narrow isthmus. The water level in the lake stays at $42.9 \mathrm{~m}$ above sea level (asl).

In the spring of 1998 a borehole was drilled through ice, which cropped out 760-cm-thick sediments of the lake. Dense clays occur at the basement of the lake sediments' core $(110 \mathrm{~cm}$ thick). They give place to greenish-brown organogenic sapropel $(650 \mathrm{~cm}$ thick).

Seventy-six samples were studied by palynological method in every 10 -cm layer. All the samples contained a great quantity of well-preserved pollen and spores except for the clay layer. Spores of pre-Quaternary (probably redeposited) vegetation were found out in clayey sediments; they represent $5-7 \%$ of the pollen and spores sum in situ.

Eleven local pollen assemblage zones (LPAZ), which correlated well with chronozones of the BlyttSernander scheme, were marked out on the chrono-palynological diagram of the lake sediments (Figure 1, Table 1).

LEM-1, 750-680 cm, varved clay, Younger Dryas. Pollen of arboreal birch (Betula sect. Albae) dominate here and have a small maximum (about 25\%). The portion of shrub (Betula sect. Fruticosae) and dwarf (Betula nana) birch is much smaller (about 10\%). The amount of Pinus pollen is about $10-15 \%$. The herb pollen (NAP) amounts to $25-35 \%$ with predomination of such herbs as Artemisia, Poaceae, Chenopodiaceae, and Cyperaceae. Selaginella selaginoides spores are also present.

According to the pollen data, birch and pine forest tundra vegetation with grasses were widespread during the Younger Dryas.

LEM-2, 680-650 cm, organic gyttja, Preboreal. Betula sect. Albae predominates the pollen spectrum (35-55\%); the amount of the Betula sect. Fruticosae and Betula nana pollen reduced to 2-5\%. The percentage of Pinus pollen did not exceed $2 \%$ and of NAP $-20 \%$.

The data obtained shows that the area occupied by tundra vegetation with shrub and dwarf birch, willow, Artemisia and Chenopodeaceae was diminished. Arboreal birch became the main forestforming species.

LEM-3a, 650-595 cm, organic gyttja, Early Boreal. The amount of arboreal species (AP) increased sharply (to 97\%) and that of NAP fall to 3\%. Pollen of Pinus predominated (55-70\%), and Betula sect. Albae (15-30\%) came next.

At the first half of the Boreal, the role of xerophytes in the landscape is reduced sharply. Pine and birch-pine forest predominated. 


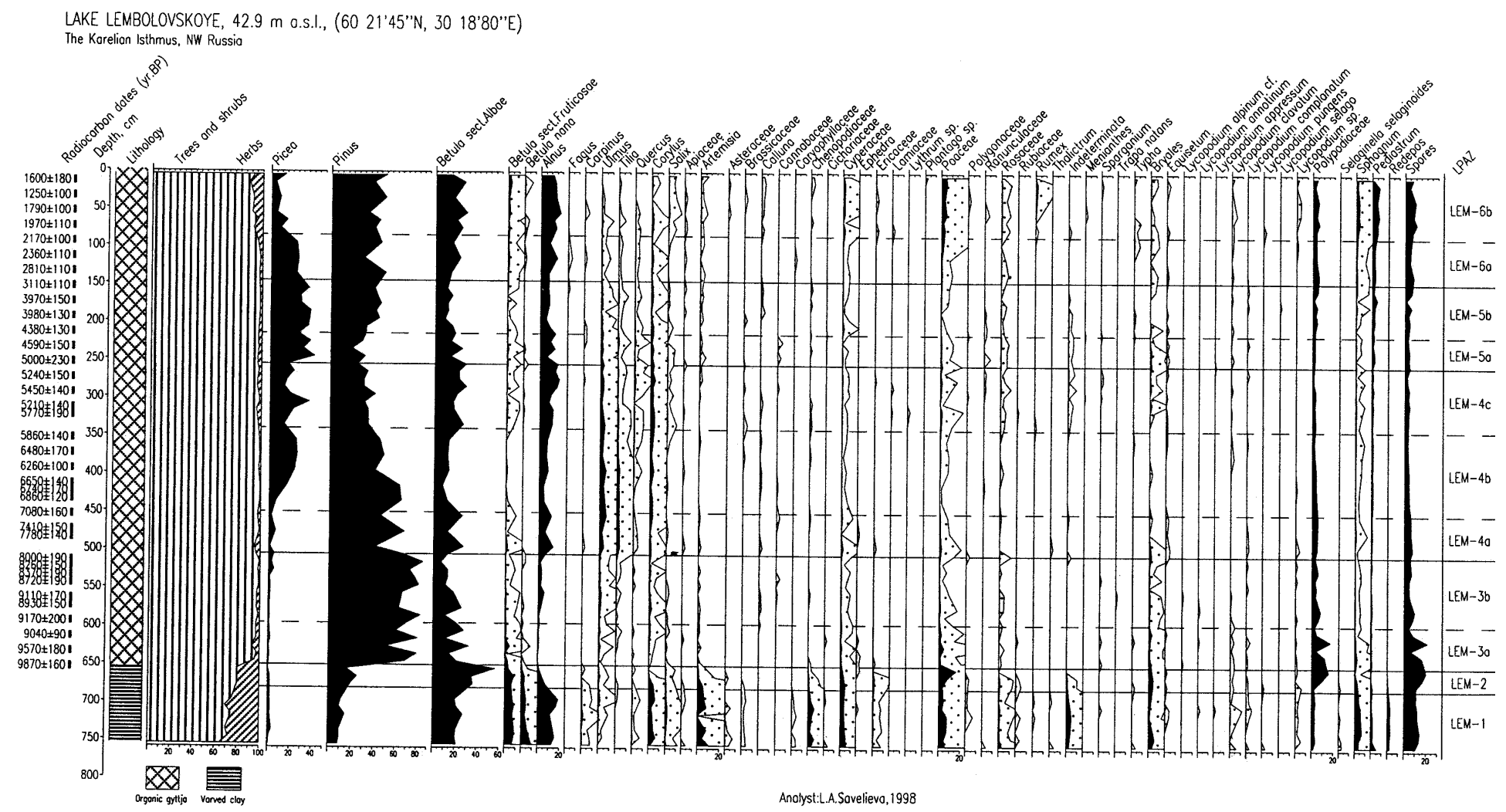


Table $1{ }^{14} \mathrm{C}$ dates of the Lembolovskoye Lake sediments

\begin{tabular}{|c|c|c|c|}
\hline Depth (cm) & $\begin{array}{l}\text { Lab code } \\
\text { LU- }\end{array}$ & ${ }^{14} \mathrm{C}$ age $(\mathrm{BP})$ & $\begin{array}{l}\text { Calibrated age } \\
\text { AD/BC }(1 \sigma)\end{array}$ \\
\hline $30-40$ & 4112 & $1250 \pm 100$ & $685-885$ AD \\
\hline $50-60$ & 4111 & $1790 \pm 100$ & 125-380 AD \\
\hline $70-80$ & 4110 & $1970 \pm 110$ & $115-210 \mathrm{AD}$ \\
\hline $90-100$ & 4109 & $2170 \pm 100$ & 360-95 BC \\
\hline $110-120$ & 4108 & $2360 \pm 110$ & 760-235 BC \\
\hline $130-140$ & 4107 & $2810 \pm 110$ & $1125-835$ BC \\
\hline $150-160$ & 4106 & $3110 \pm 110$ & $1515-1215 \mathrm{BC}$ \\
\hline $170-180$ & 4105 & $3970 \pm 150$ & $2840-2205 \mathrm{BC}$ \\
\hline $190-200$ & 4104 & $3980 \pm 130$ & $2835-2235 \mathrm{BC}$ \\
\hline $210-220$ & 4103 & $4380 \pm 130$ & $3330-2880 \mathrm{BC}$ \\
\hline $230-240$ & 4102 & $4590 \pm 150$ & $3520-3095$ BC \\
\hline $250-260$ & 4101 & $5000 \pm 230$ & $4215-3520 \mathrm{BC}$ \\
\hline $270-280$ & 4100 & $5240 \pm 150$ & $4315-3820 \mathrm{BC}$ \\
\hline $290-300$ & 4099 & $5450 \pm 140$ & $4450-4050 \mathrm{BC}$ \\
\hline $310-320$ & 4098 & $5210 \pm 140$ & $4225-3805 \mathrm{BC}$ \\
\hline $320-330$ & 4131 & $5770 \pm 190$ & $4835-4365 \mathrm{BC}$ \\
\hline $350-360$ & 4096 & $5860 \pm 140$ & $4905-4545 \mathrm{BC}$ \\
\hline $380-390$ & 4128 & $6270 \pm 160$ & $5465-5005 \mathrm{BC}$ \\
\hline $390-400$ & 4094 & $6260 \pm 100$ & $5320-5060 \mathrm{BC}$ \\
\hline $400-410$ & 4127 & $6650 \pm 190$ & $5730-5375$ вC \\
\hline $410-420$ & 4093 & $6650 \pm 140$ & $5710-5475 \mathrm{BC}$ \\
\hline $420-430$ & 4126 & $6740 \pm 170$ & $5775-5485 \mathrm{BC}$ \\
\hline $430-440$ & 4092 & $6860 \pm 120$ & $5865-5635$ BC \\
\hline $450-460$ & 4091 & $7080 \pm 160$ & $6155-5785 \mathrm{BC}$ \\
\hline $460-470$ & 4124 & $7310 \pm 160$ & $6375-6015 \mathrm{BC}$ \\
\hline $470-480$ & 4090 & $7410 \pm 150$ & $6405-6095 \mathrm{BC}$ \\
\hline $490-500$ & 4089 & $7510 \pm 150$ & $6495-6115 \mathrm{BC}$ \\
\hline $510-520$ & 4088 & $8000 \pm 190$ & $7300-6650 \mathrm{BC}$ \\
\hline $520-530$ & 4121 & $8260 \pm 150$ & $7515-7080 \mathrm{BC}$ \\
\hline $530-540$ & 4087 & $8370 \pm 190$ & $7585-7085 \mathrm{BC}$ \\
\hline $540-550$ & 4120 & $8720 \pm 190$ & $8195-7585 \mathrm{BC}$ \\
\hline $560-570$ & 4119 & $9110 \pm 170$ & $8600-7975 \mathrm{BC}$ \\
\hline $570-580$ & 4083 & $8930 \pm 150$ & $8270-7840 \mathrm{BC}$ \\
\hline $590-600$ & 4081 & $9170 \pm 200$ & $8720-8025$ BC \\
\hline $610-620$ & 4079 & $9040 \pm 90$ & $8411-7973$ BC \\
\hline $620-630$ & 4115 & $9830 \pm 150$ & 9605-8940 BC \\
\hline $630-640$ & 4116 & $9570 \pm 180$ & $9215-8655 \mathrm{BC}$ \\
\hline $650-660$ & 4078 & $9870 \pm 160$ & $9685-9185 \mathrm{BC}$ \\
\hline
\end{tabular}

${ }^{a}$ Radiocarbon ages are corrected to calibrated ages according to the Groningen Calibration Program version CAL25. 
LEM-3b, 595-505 cm, organic gyttja, Late Boreal. Pinus pollen still dominated (60-80\%), Betula sect. Albae was a little less than 30\%. Ulmus- and Corylus- pollen were present constantly (2-3\%) and Alnus appearred (2-5\%).

The data suggests wide spreading pine forests with an admixture of birch and alder. The thermophilic flora occurred in the forests, elm and hazel in the first turn but their amount is negligible.

LEM-4a, 505-450 cm, organic gyttja, Early Atlantic. The amount of Picea pollen decreased sharply (to 45\%) and that of Alnus-, Ulmus-, Tilia- and Quercus-pollen increased.

During this period pine and birch remained, as before, the main forest-forming species. The broadleaved species (elm and line), hazel and alder have increased in importance.

LEM-4b, 450-340 cm, organic gyttja, Middle Atlantic. A rise in the Picea pollen curve (to 25\%) is observed. The amount of Pinus-pollen was 40-63\% and that of Alnus-pollen was about 15\%. The percentage of Alnus pollen diminished and that of the broad-leaved species varied from 4 to $8 \%$.

Pollen data shows in the middle of the Atlantic an intensive expansion of spruce forests; spruce pine and spruce-birch-pine, with an admixture of broad-leaved species, hazel and alder began to be formed.

LEM-4c, 340-255 cm, organic gyttja, Late Atlantic. Pinus- and Betula sect. Albae pollen curves are similar. The amount of Picea-pollen was changed from 14 to 36\%, that of Alnus from 8 to $19 \%$ and the share of broad-leaved species varied from 3 to $7 \%$.

Pollen data demonstrate that towards the end of the Atlantic, spruce lost its important role in the composition of the forest.

LEM-5a, 255-215 cm organic gyttja, Early Subboreal. Pollen of Pinus (32-45\%) and Picea (2937\%) dominated in the spectra. The percentage of Betula sect. Albae and Alnus decreased noticeably: to $9-10 \%$ and 5-8\%, respectively. Pollen of Tilia and Quercus occurred sporadically.

The beginning of the Subboreal was characterized by new spruce expansion: spruce formed great forest tracts (spruce and birch-pine-spruce forests). Thermophilic flora was present only as a negligible admixture.

LEM-5b, 215-145 cm, organic gyttja, Late Subboreal. The maximum of Picea-pollen is fixed (43\%). Other components of the pollen spectra (such as Pinus, Betula sect. Albae, Alnus) remained in the same relationship as in LPAZ of LEM-5a. Fagus-pollen appeared among the broad-leaved species but its total amount did not exceed $2 \%$.

Thus, spruce remained the main forest-forming species but the role of pine and birch increased gradually; the thermophylic flora elements vanished.

LEM-6a, 145-85 cm, organic gyttja, Early Subatlantic. The percentage of Picea-pollen decreased to $25 \%$ and that of Betula sect. Albae and Alnus increased moderately. The amount of the broad-leaved species pollen (Carpinus, Fagus, Ulmus, Tilia, Quercus) occurred sporadically.

The pollen data indicate that at the beginning of the Subatlantic spruce forests began to diminish gradually. Pine and birch forests with an admixture of spruce were formed. 
LEM-6b, 85-00 cm, organic gyttja, Late Subatlantic. Picea-pollen were dominant (43-60\%); the amount of Betula sect. Albae pollen was 15-30\% and that of Alnus was 12-15\%. The percentage of Picea pollen did not exceed 15\%. The amount of NAP pollen increased to $13 \%$.

During the Late Subatlantic pine forests with birch were spread; alder grew on the over- moistened areas. At the same time herbs (mostly, Gramineae, sedge, sorrel) and shrub were increasing in importance.

Thirty-six ${ }^{14} \mathrm{C}$ dates have been obtained for this section at the Geochronological Laboratory of the Geogaphical Research Institute, St Petersburg University (Table 1).

\section{Mshinskoye Bog Section (59 $\left.52^{\prime} 00^{\prime \prime} \mathrm{N}, 2^{\circ} 55^{\prime} 00^{\prime \prime} \mathrm{E}\right)$}

Mshinskoye bog is located at the south of the Leningrad province. It is stretches $30 \mathrm{~km}$ from south to north and 10-12 km from west to east. The lake occupies its central part; its southern stretch is called Vyalie Lake, the northern one-Strechno Lake. The lake length from the south to the north is $16 \mathrm{~km}$; its surface is about $36 \mathrm{~km}^{2}$. In October 1997, a 600-cm-deep borehole was drilled. It cropped out a thickness of peat $(590 \mathrm{~cm})$, underlying sand $(5 \mathrm{~cm})$, and blue varved clay $(10 \mathrm{~cm})$ layers.

Sixty samples, collected every $10 \mathrm{~cm}$, have been studied by palynological methods. The chronopalynological diagram allows marking out 11 local pollen assemblage zones (LPAZ) (Figure 2, Table 2). It has been found that the peat formation began in the Late Preboreal.

MSH-1a, 605-575 cm, varved clay, sand, peat, Early Preboreal (PB-1). The zone is characterized by predomination of pollen of Betula sect. Albae (to 65\%). Betula sect. Fruticosae is 5-20\% and Betula nana $-2-5 \%$. Salix pollen is present (5-7\%). A relatively high pollen percentage of herbs (NAP 15$38 \%$ ) is of a great importance for the zone, Cyperacea and Poacea are dominant among them.

According to the spore-pollen data, sparse birch forests with an admixture of shrub and dwarf birch, and also willow were dominant in the Early Preboreal. Herb groups from Cyperacea and Podeacea grew on the open area.

MSH-1b, 575-520 cm, peat, Late Preboreal (PB-2). A reduction of herbs (to 20\%) and an increase of Pinus-pollen (15-20\%) is characteristic for the zone. Ulmus-pollen occurred. Other components of the spore-pollen spectra remained in the same relationship. In the Late Preboreal pine began to be of importance in pine-birch forests; herbs were spread as earlier.

MSH-2, 520-450 cm, peat, Boreal (BO), A sharp increasing of Betula sect. Albae-pollen (60-70\%) is observed in the zone. The amount of Pinus-pollen changes from 7 to $25 \%$. The percentage of NAP did not exceed $10 \%$. An abrupt rise in the Alnus-curve is observed to the end of the zone. Pollen of Tilia, Quercus, Corylus and aslo Picea appeared.

The data shows that birch forests with an admixture of pine were widespread on the territory under study during the Boreal. The open area occupied by herb groupings from Cyperacea, Poacea, Artemisia, Chenopodiacea diminished abruptly. Spruce and thermophilic flora occurred in the forest composition.

MSH-3a, 450-370 cm, peat, Early Atlantic (AT-1). A reduction of the amount of Betula sect. Albaeto $30 \%$ and Pinus pollen to $10 \%$ and also an increase in that of Alnus (to 25\%), Picea (to 12\%), Ulmus (to $8 \%$ ), and Corylus (to 10\%) are the key features for this zone. The amount of NAP is very low. 
MSHINSKOYE RAISED BOG

Luga region, NW Russio

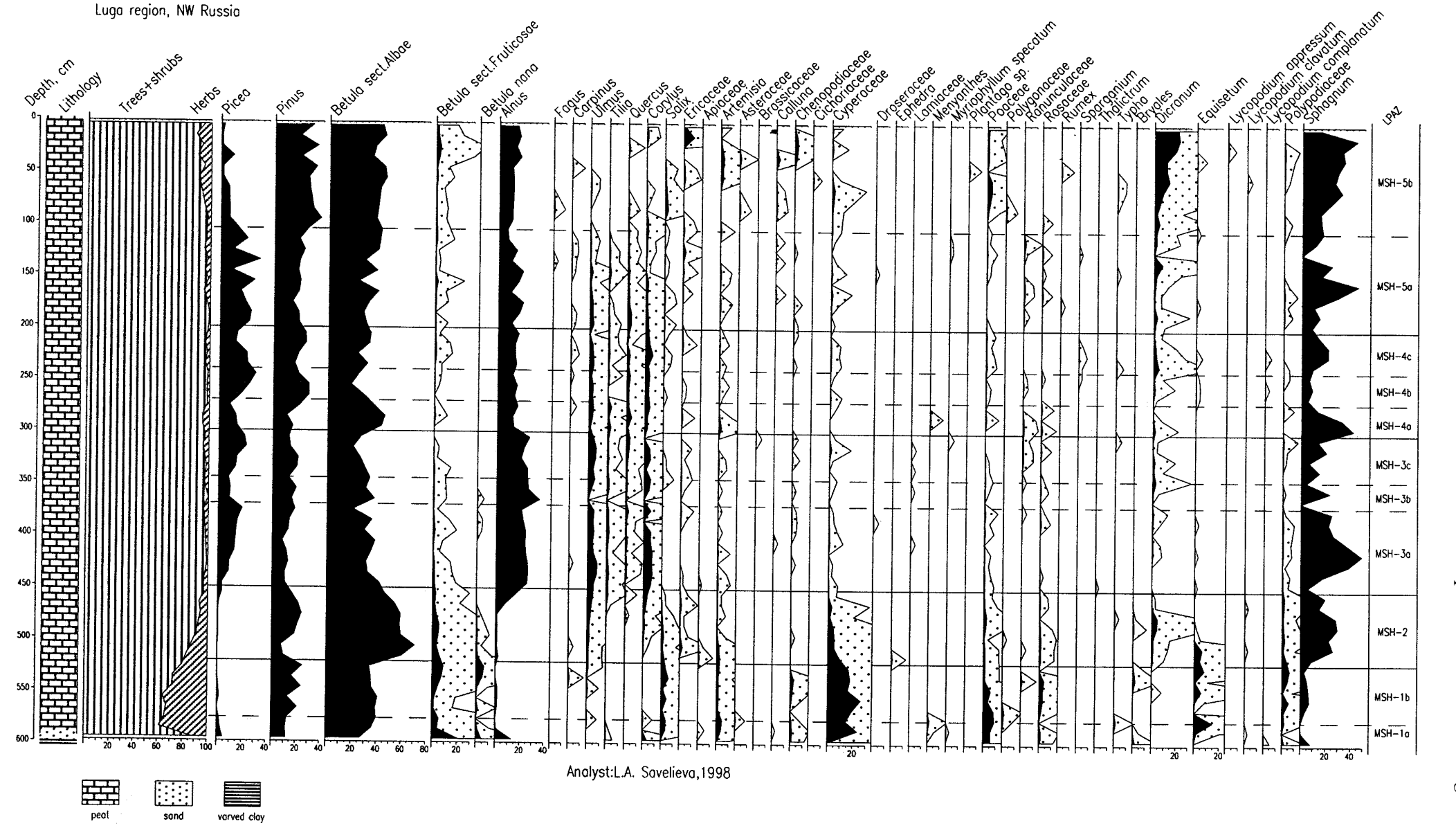

Figure 2 Chrono-palynological diagram of the Mshinskoye raised bog sediments 
Spruce-pine-birch forests with an admixture of broad-leaved trees (elm, lime, oak), hazel and alder predominated on the territory during the Early Atlantic.

MSH-3b, 370-345 cm, peat, Middle Atlantic (AT-2). There is a maximum of $35 \%$ on the Alnus pollen curve. Also the Picea pollen curve has a small maximum of about $20 \%$. The percentage of Ulmus, Tilia, Quercus and Corylus pollen decreased sharply. The amount of Betula sect. Albae- and Pinus-pollen varied from 25 to $40 \%$ and from 15 to $20 \%$, respectively.

In the Middle Atlantic the share of thermophilic flora reduced; arboreal birch and pine remained the main forest-forming species.

MSH-3c, 345-305 cm, peat, Late Atlantic (AT-3). A maximum pollen amount of broad-leaved species in total is characterized for this zone: Ulmus (9\%), Tilia (1-2\%), Quercus (2-3\%). (It is the maximum amount for the whole section). A small maximum of Picea-pollen (20\%) is observed to the end of the zone.

Against the background of a domination of spruce-pine-birch forests, the favorable climatic conditions in the Late Atlantic promoted the wide expansion of thermophilic flora.

MSH-4a, 305-270 cm, peat, Early Subboreal (SB-1). The amount of Betula sect. Albae-pollen increased sharply (to 45\%), that of Pinus is 8-12\%, Picea 7-12\%, Alnus 5-17\%. A share of Ulmus reduced 2-3\% and that of Tilia and Quercus increased 1-2\%.

During the Early Subboreal, birch was the main forest-forming species. Birch forests with pine and spruce were developed on the area under study. The broad-leaved trees presented also a small admixture.

MSH-4b, 270-240 cm, peat, Middle Subboreal (SB-2). A maximum of Picea-pollen (30\%) for the whole section is fixed in this zone. The percentage of Pinus increased to 20-25\% and Betula sect. Albae decreased to 15-20\%. Among the broad-leaved species pollen of Carpinus occurred.

In the Middle Subboreal, spruce achieved the maximum expansion and became the forest-forming species.

MSH-4c, 240-200 cm, peat, Late Subboreal (SB-3). The amount of pollen from the broad-leaved species reduced gradually. The percentage of Betula sect. Albae was 20-35\%, Pinus 20\%, and Picea $10-15 \%$.

Birch, pine and spruce remained the forest-forming arboreal species. Thermophilic flora elements vanished from the forest composition.

MSH-5a, 200-195 cm, peat, Early Subatlantic. The pollen curves for the principal components of spore-pollen spectra in this zone are similar to that of LPAZ LEM-6a, what is represented in the diagram of the Lembolovskoye Lake section (Figure 1).

MSH-5b, 105-00 cm, peat, Late Subatlantic. In this zone the pollen curves for the principal components of spore-pollen spectra in this zone are similar to that of LPAZ LEM-6b (Figure 1). We obtained $32{ }^{14} \mathrm{C}$ dates the Mshinskoye bog section (Table 2).

\section{DISCUSSION}

Correlating chrono-palynological diagrams of the sections in Northwestern Russia: Lambolovskoye Lake and Mshinskoye Bog with the sections studied earlier (sections: Nikolsko-Lutinskoye Bog, 
Table $2{ }^{14} \mathrm{C}$ dates of Mshinskoye raised bog sediments

\begin{tabular}{cccl}
\hline & $\begin{array}{c}\text { Lab code } \\
\text { Depth }(\mathrm{cm})\end{array}$ & $\begin{array}{c}\delta^{14} \mathrm{C}(\%) \text { or } \\
{ }^{14} \mathrm{C} \text { age }(\mathrm{BP})\end{array}$ & $\begin{array}{c}\text { Calibrated age } \\
(\mathrm{AD} / \mathrm{BC})\end{array}$ \\
\hline $30-40$ & 4053 & $1087 \pm 8.0$ & \\
$40-50$ & 4054 & $60 \pm 70$ & \\
$50-60$ & 4055 & $70 \pm 80$ & \\
$100-110$ & 4063 & $1380 \pm 100$ & $560-775 \mathrm{AD}$ \\
$110-120$ & 4041 & $1810 \pm 240$ & $45 \mathrm{BC}-530 \mathrm{AD}$ \\
$130-140$ & 4040 & $1870 \pm 90$ & $29-313 \mathrm{AD}$ \\
$150-160$ & 4039 & $2120 \pm 80$ & $351-3 \mathrm{BC}$ \\
$160-170$ & 4084 & $2500 \pm 90$ & $787-519 \mathrm{BC}$ \\
$170-180$ & 4038 & $2770 \pm 100$ & $1020-810 \mathrm{BC}$ \\
$190-200$ & 4037 & $2740 \pm 100$ & $1000-805 \mathrm{BC}$ \\
$210-220$ & 4036 & $3030 \pm 100$ & $1405-1130 \mathrm{BC}$ \\
$230-240$ & 4035 & $3400 \pm 90$ & $1871-1531 \mathrm{BC}$ \\
$240-250$ & 4076 & $3800 \pm 100$ & $2455-2045 \mathrm{BC}$ \\
$250-260$ & 4034 & $3990 \pm 80$ & $2621-2349 \mathrm{BC}$ \\
$290-300$ & 4032 & $3790 \pm 80$ & $2397-2047 \mathrm{BC}$ \\
$310-320$ & 4031 & $4290 \pm 100$ & $3085-2700 \mathrm{BC}$ \\
$330-340$ & 4030 & $4620 \pm 100$ & $3625-3105 \mathrm{BC}$ \\
$350-360$ & 4029 & $4690 \pm 80$ & $3627-3371 \mathrm{BC}$ \\
$370-380$ & 4028 & $5390 \pm 100$ & $4335-4050 \mathrm{BC}$ \\
$390-400$ & 4027 & $5570 \pm 100$ & $4520-4260 \mathrm{BC}$ \\
$410-420$ & 4026 & $6130 \pm 150$ & $5260-4855 \mathrm{BC}$ \\
$420-430$ & 4077 & $6020 \pm 90$ & $5035-4799 \mathrm{BC}$ \\
$440-450$ & 4080 & $7150 \pm 120$ & $6200-5845 \mathrm{BC}$ \\
$450-460$ & 4024 & $7520 \pm 110$ & $6445-6245 \mathrm{BC}$ \\
$460-470$ & 4082 & $7670 \pm 130$ & $6650-6390 \mathrm{BC}$ \\
$470-480$ & 4023 & $8160 \pm 150$ & $7470-6835 \mathrm{BC}$ \\
$490-500$ & 4022 & $8890 \pm 180$ & $8260-7765 \mathrm{BC}$ \\
$500-510$ & 4018 & $8920 \pm 330$ & $8410-7610 \mathrm{BC}$ \\
$510-520$ & 4017 & $9740 \pm 190$ & $9385-8790 \mathrm{BC}$ \\
$530-540$ & 4016 & $9700 \pm 140$ & $9275-8815 \mathrm{BC}$ \\
$540-550$ & 4015 & $9700 \pm 160$ & $9280-8805 \mathrm{BC}$ \\
$550-560$ & 4014 & $9450 \pm 70$ & $9093-8611 \mathrm{BC}$ \\
$560-570$ & 4013 & $9450 \pm 60$ & $9089-8629 \mathrm{BC}$ \\
$570-580$ & 4012 & $9950 \pm 160$ & $9735-9250 \mathrm{BC}$ \\
$580-590$ & 4011 & $9520 \pm 170$ & $9165-8635 \mathrm{BC}$ \\
\hline & & & \\
50 & & \\
50 & &
\end{tabular}

Lammin-Suo Bog, Vishnevskoye Lake, Sakkala Bog, Suo Bog, see Figures 1-5 and Tables 1-5 in Arslanov et al. 1999; Chernova et. al. 1997), we revealed characteristic peculiarities of the sporepollen spectra for the Younger Dryas and Holocene. A presence of herbs (from 20\% to 40\% in the total composition) is characteristic for the spore-pollen spectra during the Younger Dryas; the pollen of Artemisia, Chenopodiaceae, Poaceae and Cyperaceae are dominant. As for arboreal species, Betula predominates there: Betula sect. Albae 15-25\%, Betula sect. Fruticosae 10-40\%, and Betula nana 5-20\%. The percentage of Pinus is 10-20\%. The pollen of Alnus is present in all spore-pollen diagrams relating to the Younger Dryas and its percentage reaches sometimes 15-20\% (see Lembo- 
lovskoye Lake). The broad-leaved species (mainly Carpinus, Ulmus and Corylus) occur only sporadically.

At the boundary of the Younger Dryas and Preboreal, the share of Betula sect. Albae pollen increased noticeably (to 50-60\%) and that of Betula sect. Fruticosae and Betula nana decreased to $10-15 \%$ and $5-10 \%$, respectively. The percentage of herbs pollen diminished to $20 \%$.

In the Preboreal, Betula sect. Albae became the dominant species and reached even 70\% (see Mshinskoye bog). The percentage of pollen varied between 15 and 45\%. Alnus and Picea pollen were fixed in all diagrams of the section under study. Poaceae and Coperaceae are in the herb pollen group.

An increase of the amount of Pinus pollen and a decrease of that of herbs served the main criterion for establishing the boundary between the Preboreal and Boreal.

In the Boreal, the percentage of Pinus pollen in lake sediments achieved $65 \%$ and in the bog it did not exceed 30\%; that of Betula sect. Albae varied from 15 to 60\%. Pollen of Alnus, broad-leaved species (Ulmus,Tilia, Quercus) and Corylus are constantly present in the Holocene spore-pollen spectra since the end of the Boreal.

The Boreal/Atlantic boundary is defined by the sharp rise of Alnus- (to 15-29\%), broad-leaved species- and Corylus- curves and also by the occurrence of Picea-pollen (approximately 2-3\%).

In the Atlantic spore-pollen spectra Betula sect. Albae, Alnus and Pinus predominate but their relationship varies strongly. The maximum percentage (in total) of broad-leaved species- and Coryluspollen is characteristic for the whole Holocene. At the middle of Atlantic the amount of Picea-pollen was about $10 \%$ but to the end of that achieved 20-25\% (Lembolovskoye Lake, Mshinskoye bog). The percentage of herbs did not exceed $5 \%$.

The Atlantic/Subboreal boundary is drowned by increasing the amount of Picea-pollen and decreasing that of Alnus and broad-leaved species (in total).

In the Subboreal, Pinus (30-60\%) and Betula sect. Albae (10-40\%) predominate in spore-pollen spectra; along with this, an appreciable amount of Picea-pollen (varied between 15 and 40\%) is observed. At the same time a sporadic presence of Fagus and Carpinus and the maximum percentage of Quercus are often fixed.

A rise of Pinus- and herb pollen curves marks the Subboreal/Subatlantic boundary. At the first half of the Subatlantic an appreciable amount of Picea-pollen (to 25-30\%) is characteristic for the sporepollen spectra. An increase in the pollen percentage of the Pinus- or Betula sect. Albae is observed. The share of herbs increases often 2-3 times in comparison with the Subboreal and achieves 10$15 \%$ with predomination of Poacea, Cyperacea, Ericacea and motley grass.

Comparing curves of the total amount of arboreal species (AP), herbs (NAP), spores and also of individual arboreal species for the sections: Lembolovskoye Lake and Mshinskoye bog and others studied earlier, we revealed general regularities of vegetation development during the Late Pleictocene and Holocene. In pollen zone SA-3, the Preboreal and the Younger Dryas stage the reduction in pollen percentage of arboreal species and increase of that of herds and spores are observed for all sections under study with the maximal amount of herb pollen in the Younger Dryas stage. Piceacurves of all the sections have a maximum in the Subboreal, although the percentage of Picea-pollen is high enough at the second half of the Atlantic and at the first half of the Subatlantic. Only towards the end of the Subatlantic its amount decreases sharply. An appearance of Picea-pollen in the sedi- 
Table 3 Dynamics of the indicator arboreal species and alder during the Holocene in the Leningrad province

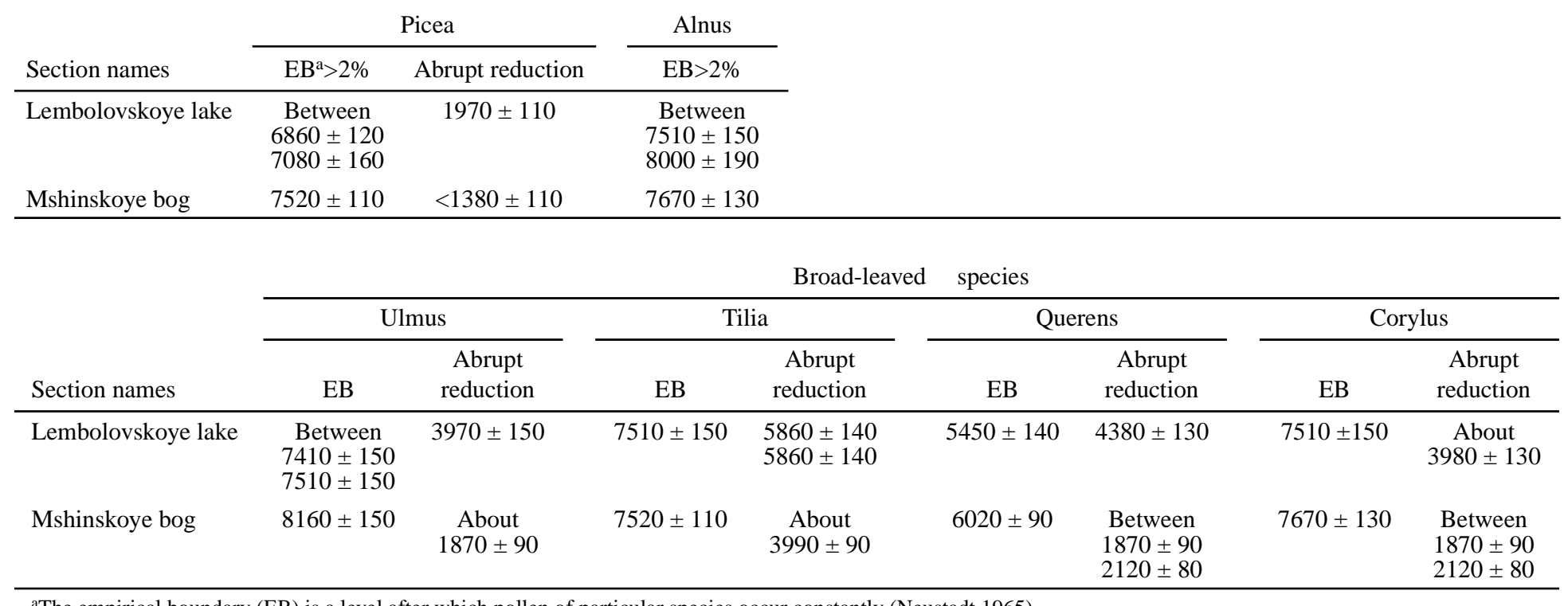

aThe empirical boundary (EB) is a level after which pollen of particular species occur constantly (Neustadt 1965). 
ments of the Lembolovskoye Lake section is dated at $6860 \pm 120 \mathrm{BP}$ and in those of the Mshinskoye bog one at $7520 \pm 110 \mathrm{BP}$ (Table 3).

Curves for pollen content of Pinus and Betula are continuous for all sections throughout the Younger Dryas and Holocene. The high content of Pinus-pollen in the Lembolovskoye Lake sediments (to $80 \%$ in the Preboreal) attracts the special attention. The amount of Pinus pollen in the bog sediments of all sections under study is much less than in the lake ones; only in the Subatlantic its content increases to 30-40\%. Betula-curve has maximum for the Lembolovskoye and Vishnevskoye Lake sediments in the Preboreal and for the bog sediments in the Younger Dryas and Preboreal (NikolskoLutinskoye Bog) and in the Preboreal and Boreal (Mshinskoye Bog, Shirinsy mokh, Lammin-Suo; Figures 1-3 in Arslanov et al. 1999). Alnus-curve becomes continuous after $7670 \pm 130 \mathrm{BP}$ for the Mshinskoye Bog and $7510 \pm 150 \mathrm{BP}$ for the Lembolovskoye Lake sections.

Pollen of thermophilic plants occur much earlier in the sediments of the Mshinskoye Bog section, which is located $180 \mathrm{~km}$ to the south of the Lembolovskoye Lake section. The data are in agreement with the regularities stated earlier for appearance of Pinus-, Alnus- and broad-leaved species-pollen in the sections located from the south towards the north (see Figures 1-5 and Table 6 in Arslanov et al. 1999). A share of broad-leaved species during the Atlantic is noticeable more (to12\%) in the Mshinskoye Bog sediments than in the Lembolovskoye Lake one located more to the north.

We used statistical information method (Klimanov et al. 1976) to reconstruct the quantitative characteristics of the Late Glacial and Holocene climates. The method is based on the statistical relationship between recent spore-pollen spectra and recent climatic conditions. The reconstruction was made on the basis of the palynological and geochronological data obtained for the Lembolovskoye Lake and the Mshinskoye bog sections. The average statistical error in determining the mean July temperature and the annual one is $\pm 0.6^{\circ} \mathrm{C}$, and that for the average annual precipitation is $\pm 25 \mathrm{~mm}$.

A great amount of radiocarbon dates enabled to attach the paleoclimatic data to the time scale but the paleoclimatic curves is not very detailed because of scarce density of palynological sampling. As a result, we construct a generalized paleoclimatic curves on the base of two sections. The data obtained are illustrated in Figure 3. and demonstrate variations of the average temperatures of July, January, the annual mean and the average annual precipitation from recent values. The changes of paleotemperatures $\left(\Delta \mathrm{t}^{0}{ }_{\text {July }}, \Delta \mathrm{t}^{\circ}{ }_{\text {January }}, \Delta \mathrm{t}^{\circ}{ }_{\text {annual }}\right)$ and of annual precipitation $(\Delta \mathrm{P})$ are represented as variations from recent temperature values. Recent climatic parameters (Climatic Atlas, 1990) for the sections under study were, on the average, as follows: mean July temperatures around $17-18^{\circ} \mathrm{C}$, mean January temperatures $8-9{ }^{\circ} \mathrm{C}$, the average annual temperature $4-5{ }^{\circ} \mathrm{C}$ and on average precipitation of $600 \mathrm{~mm}$ per year.

We will not discuss here the quantitative characteristics of $\Delta \mathrm{t}^{0}{ }_{\mathrm{a}}$ because they are shown in Figure 3. We shall consider the time of extremes of climatic deterioration and amelioration.

The data obtained shows evidence that the Younger Dryas was the coldest period, after which the rhythmic amelioration began. Four progressively warm periods were marked out during the Preboreal. A similar picture is observed for the four deteriorations that separated these warm periods. The mean January and the annual temperatures, especially illustrate it. In the Boreal two amelioration are reconstructed and the last one is dated at $8500 \mathrm{BP}$ as well as in other areas of Northern Eurasia. A noticeable cooling was recorded at the boundary of the Boreal and Atlantic. During the Atlantic several ameliorations were reconstructed and the maximum one-the Holocene maximum - was recorded at about $5500 \mathrm{BP}$; the next one dated at 6000 was not as warm. At the boundary of the AT and SB we recorded a climatic deterioration dated at around $4500 \mathrm{BP}$ as it was in other regions of 


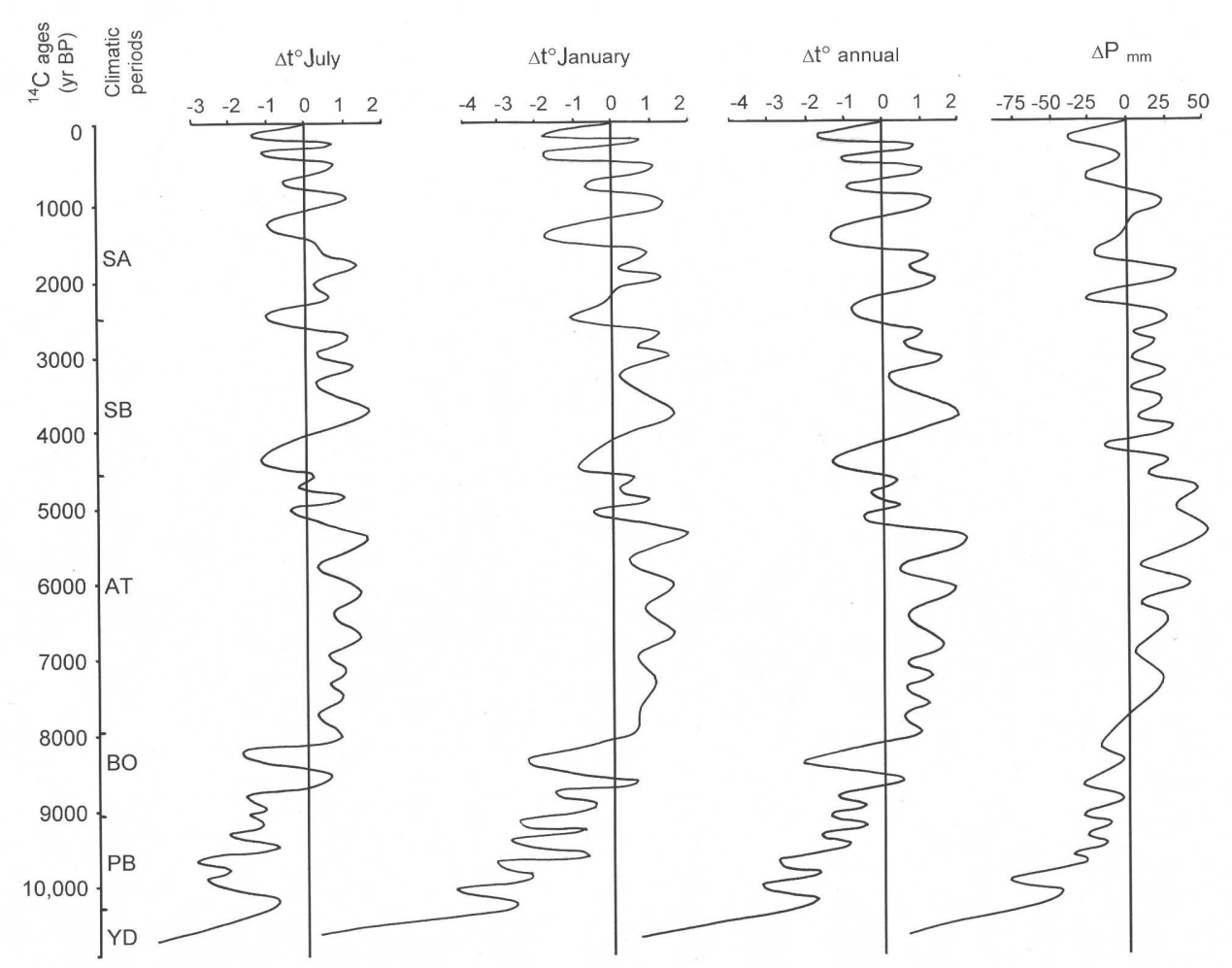

Figure 3 Deviations of the mean July, January, and annual temperatures, as well as annual precipitation from the recent temperature values during the Late Glacial and Holocene in Lenigrad province reconstructed on the bases of chrono-palynological data of the Lembolovskoye Lake and Mshinskoye raised bog sediments (total curve).

Northern Eurasia. In the Subboreal three climatic deteriorations were reconstructed; the first (at around $4000 \mathrm{BP}$ ) was the maximum as contrasted to other regions, where the maximum SB warming were observed at around 3500 BP. It could be connected with local characteristics of climate changes or a sparse density of sampling for spore-pollen analysis, i.e. the maximum warming at $3500 \mathrm{BP}$ was missed. At the beginning of the Subatlantic (at around $2500 \mathrm{BP}$ ) a climatic deterioration was recorded as in other regions. The trend towards the systematic climatic deterioration occurred during the SA: every next cooling was colder than the previous one. This is well traced by changing the mean July temperatures. The last cooling before present was the coldest: it was the Little Ice Age, with a maximum in the 17th century. As for the relationship between temperatures and precipitation, it can be said that climatic ameliorations were followed by increase of precipitation and vice versa, the deteriorations were followed by a decrease in it.

Thus, a trend towards warming was marked out since the Late Glacial to the Holocene optimum, and towards cooling since the Holocene optimum to the present. The amplitude of changes in the mean January temperatures was greater than that of mean July. In the sections under study, the detailed climatic changes during the Preboreal and Boreal were reconstructed, as distinguished from other regions studied earlier. The ${ }^{14} \mathrm{C}$ data show that wide temperature changes during the Late Glacial and Holocene in the Karelian Isthmus and southwestern Leningrad province were the same as in other regions of Northern Eurasia. 


\section{CONCLUSION}

A reference chrono-palynological diagram has been constructed on the base of the detailed conjugated palynological and geochronological investigations of the Lembolovskoye Lake and Mshinskoye Bog sections. It enabled us to mark out pollen assemblage zones (PAZ), which were correlated with climatic periods and phases of the Blytt-Sernander scheme since the Younger Dryas stage to the Subatlantic. They were also correlated with the stages of paleoclimatic changes stated on the base of processing the chrono-palynological data by the information-statistic method. The time of appearance and disappearance of the indicator species of trees and alder during the Holocene and also the time of their migration from south towards the north was set up. Comparison of the data obtained now and that obtained earlier for six sections located in the Leningrad and Novgorod provinces shows a similarity of the spore-pollen spectra for arboreal species. The percentage of Pinus is found to be noticeably higher in lake sediments than in bog ones. ${ }^{14} \mathrm{C}$ chronology for the stages of vegetation development and paleoclimate changes during the Younger Dryas and Holocene has been set up. Younger Dryas/Preboreal transition in Northwestern Russia is characterized by transformation of birch and pine forest-tundra vegetation involving shrub and dwarf birch, willow, xerophytic herbs, grasses to sparse birch forests with admixture of shrub and dwarf birch and willow also.

According to paleoclimatic reconstruction the mean annual temperature during the coldest time of Younger Dryas, about 10,500-10,700 BP, was approximately $6{ }^{\circ} \mathrm{C}$ lower than annual recent temperature (see Figure 3 in this article and Figure 6 in Arslanov et al. 1999). At the beginning of Holocene mean annual temperature was about $2{ }^{\circ} \mathrm{C}$ lower than that at present.

\section{ACKNOWLEDGMENT}

This study was supported by the Russian Foundation for Fundamental Investigations (RFFI), grant 100-05-64833.

\section{REFERENCES}

Arslanov KhA, Tertychnaya TV, Chernov SB. 1993. Problems and methods of dating low activity samples by liquid scintillation counting. Radiocarbon $35(3)$ : 393-8.

Arslanov KhA, Saveljeva LA, Gey NA, Klimanov VA, Chernov SB, Chernova GM, Kuzmin GF, Tertychnaya TV, Subetto DA, Denisenkov VP. 1999. Chronology of vegetation and paleoclimatic stages of northwestern Russia during the Late Glacial and Holocene. Radiocarbon 41(1):25-45.

Chernova GM, Arslanov KhA, Denisenkov VP, Sevastjanov DB, Tertychnaya TV, Okuneva EJu, Chernov SB. 1997. Paleoecology and the biological variety of vegetation of the northwestern Lake Ladoga area during the Holocene. Vestnik of St. Petersburg University.
Series 7;4: 128-37, In Russian.

Climatic Atlas of the USSR. 1990. Volume 1. In Russian. Elina GA, Arslanov KhA, Klimanov VA. 1996. Development stages of Holocene vegetation in Southern and Eastern Karelia. Botanical Journal 81(3):1-17. In Russian.

Klimanov VA. 1976. On the procedure of reconstruction of the quantitative climatic characteristics of the past. Vestnik of Moscow State University, Geographical Series 2: 92-8. In Russian.

Neustadt MI. 1965. On the method of Holocene sediment study and the terms applied. In: Neustadt MI, editor. Paleogeography and chronology of the Late Pleistocene and Holocene. Publishing House of Academy of Sciences. p 66-9. In Russian. 